International Journal of Linguistics, Literature and Culture
Available online at https://sloap.org/journals/index.php/ijllc/
Vol. 5, No. 5, September 2019, pages: 29 35
$\begin{aligned} & \text { ISSN: 2455-8028 } \\ & \text { https://doi.org/10.21744/ijllc.v5n5.738 }\end{aligned}$

\title{
Intercultural Communication Based on Ideology, Theology and Sociology
}

\author{
I Gusti Ayu Ratna Pramesti Dasih a \\ Ida Bagus Gde Yudha Triguna ${ }^{b}$ \\ I Wayan Winaja ${ }^{c}$
}

Article history:

Received: 18 March 2019

Accepted: 31 July 2019

Published: 07 September 2019

\section{Keywords:}

communication;

ideology;

sociology;

temple;

theology;

\begin{abstract}
The research was intended at exploring the intercultural communication based on ideology, theology, and sociology on Pura Dalem Solo. It was pura kahyangan jagat. Those have occurred many activities reflected intercultural communication. Intercultural communication raised some interesting things to study in order to formulate findings that can be used as a cultural reflection facing the global era. The existence of the temple was also related to history, tradition, and culture. They have accumulated from past thought. Therefore, it manifests in the form of multicultural culture and becomes a scientific study. The temple might be stated as an iconic culture. It was built from intercultural communication involving several things unlike, processes, patterns, and implications arise in intercultural communication. A cultural icon becomes the basis of study. It can then be seen on the temple not only as a sacred place but also as a communication medium. In this case cultural symbols were messages, and the pengempon-penyiwi resident were communicants or recipients as well as subjects who treat the message.
\end{abstract}

2455-8028 ${ }^{\circ}$ Copyright 2019. The Author. This is an open-access article under the CC BY-SA license (https://creativecommons.org/licenses/by-sa/4.0/) All rights reserved.

\section{Author correspondence:}

I Gusti Ayu Ratna Pramesti Dasih,

Universitas Hindu Indonesia, Denpasar, Indonesia

Email address: igustiayuratnapramesti@gmail.com

${ }^{a}$ Universitas Hindu Indonesia, Denpasar, Indonesia

${ }^{\mathrm{b}}$ Universitas Hindu Indonesia, Denpasar, Indonesia

${ }^{\mathrm{c}}$ Universitas Hindu Indonesia, Denpasar, Indonesia 


\section{Introduction}

Pura Dalem Solo in Sedang Village, Abiansemal Subdistrict, Badung Regency is one of the unique temples of historical heritage. It is included in cultural preservation. Pujawali (festival day) in Pura Dalem Solo are attended and disungsung (managed) by the local community as well as was attended by Sesuhunan Keraton Yogyakarta. Intercultural communication has occurred when pujawali held. Pura Dalem Solo has several palinggih (part of temple). The one who sthana (stays) in Pura Dalem Solo is Ida Ratu Sakti. Pura Dalem Solo also has several other palinggih unlike, Bedugul, Beraban or Ulun Suwi. Sang Hyang Baka Bhumi was worshiped in Ulun Suwi. who provided welfare. Pura Dalem Solo basically has a function as the balance or stability of the universe and agricultural protection from pests (nangluk merana). The existence of Pura Dalem Solo consisted of the Lontar Tattwa Catur Bhumi.

Intercultural communication is found in Pura Dalem Solo was holding pujawali. All palinggih are decorated in accordance with Hindu traditions in Bali. However, palinggih Ida Ratu Subandar is decorated with red lanterns and Chinese ornaments like a pagoda. The named Pura Dalem Solo is also unique. Solo is one of the cities in Central Java province. Pura Dalem Solo initially was known as the Pura Kauh, then in 1965, the name was changed to be Pura Dalem Majapahit. The name change to Pura Dalem Solo occurred in 1976. There was an earthquake that only occurred in the temple area to coincide with the pujawali implementation. There was a pengempon (societies of temple) who was kesurupan (possessed) said that Ratu Dalem Solo was to rauh (come). It was named Pura Dalem Solo until present. Therefore, the intercultural communication found in Pura Dalem Solo, namely the blending of Balinese, Javanese, and Chinese cultures into a harmonious whole in Pura Dalem Solo.

\section{Materials and Methods}

The present study applied qualitative methods. All data is analyzed descriptively. It is used a paraphrase to explain, elaborate, and explore regarding the phenomenon belonging (Sabilah, 2016). The conclusion is the last remarked based on the previous result and discussion.

\section{Results and Discussions}

The basic thing about intercultural communication in Pura Dalem Solo is the historical background, ideology, theology, and sociology. The backgrounds may be stated as reasons for the process of intercultural communication in Pura Dalem Solo. Although, there are differences in the historical version of the existence of Pura Dalem Solo. There are several things need to be stressed that the existence of Pura Dalem Solo is closely related to the cultural relations of Bali and Java, which then emerged Chinese culture. As explained in the Lontar Tattawa Catur Bumi that the existence of Pura Dalem Solo is closely related to the journey of the saint Ida Ratu Sakti accompanied by his followers from Majalangu, Java to Bali, until finally settling in an area called Puri Dalem Sala and eventually became Pura Dalem Solo.

\subsection{Intercultural Communication Process}

The beginning of being Chinese culture and belief namely, the worship of Ida Ratu Subandar is closely related to the ideology on Pura Dalem Solo as a temple oriented to worship of fertility and everything related to Hindu religious for pengempon-penyiwi residents. Triguna (2017), explained that the practice of Hinduism in Bali aims to fulfill human religious needs. It is not only ideology, theologically but also clearly demonstrated the worship of fertility in Pura Dalem Solo was important, in the past and for the present. Fertility theology in Pura Dalem Solo can be proven by the discovery of archeological remains in the form of the Lingga Guru, statue, and worship of Ida Ratu Subandar. Based on historical, ideological, and theological understandings, sociologically the pengempon-penyiwi residents also carry out social interactions. It defines humans as social beings are never far from the social relations name.

The intercultural communication process essentially is the same as other communication processes, namely an interactive, transactional, and dynamic process. One example is interactive intercultural communication carried out by pengempon-penyiwi residents, Pura Dalem Solo. There implicitly reflects intensive communication by the 
communicator with the communicant in two directions or reciprocity through several stages. It has occurred in doing pujawali at Pura Dalem Solo. The pengempon residents has been coordinated by kelian paletan to communicate everything related to pujawali. The pengempon residents respond and communicate everything to the temple, therefore, two-way communication has occurred. The communicator, in this case, in intercultural communication is the party who initiated communication. Communicating in intercultural communication is the party who receives a particular message will be the objective or target of another party's communication (communicator). The purpose of communication will be achieved when the communicant receives the communicator's message and pays attention to and receives the message as a whole.

The intercultural communication process depends on the stages that involve the seven elements of intercultural communication. Devito (2017) \& Liu (2018), it can be understood. There are seven elements in intercultural communication, namely people or humans, messages, media, feedback, codes, encoding-decoding, and noise. Therefore, the seven culture elements are important on describing the process of intercultural communication that there are certain stages. The previous discourse description was directed at the initial phase, how the process of intercultural communication takes place in Pura Dalem Solo. It is based on the historical narrative of the establishment of the Pura Dalem Solo. It is explained on the description that the stages of the communication development occur relating to the seven elements of intercultural communication. The discourse on the intercultural communication component is one component that forms intercultural communication (Endraswara, 2017). There is through discourse a process of cultural exchange. there are exchange verbal and nonverbal elements. The existence of Pura Dalem Solo on this context can be stated to be the center of the exchange of cultural discourse. There is loaded with magic namely, the cultural discourse of Bali, Java, and China.

\subsection{Intercultural Communication Pattern}

The patterns of intercultural communication applied in Pura Dalem Solo include several patterns, namely oneway, two-way or reciprocal communication. Those include the process of delivering, receiving, and treating messages through the media and without the media. One-way intercultural communication pattern, pengemponpenyiwi residents in Pura Dalem Solo as communicants are only recipients and listeners. It defines, there is not provide response and feedback to all messages through the media. Therefore, the societies only treat the media in the form of symbolic actions that represent intercultural cultures in Pura Dalem Solo.

These symbolic actions are based on the pengempon-penyiwi resident's encouragement in Pura Dalem Solo to treat its media. The media on this context is all matters relating to the citizen's activities in Pura Dalem Solo with various bases of action in it. They carry out various activities on the basis of religious, social, and ethical based on norms of the action. The norm is based on a growing discourse, namely Pura Dalem Solo is a sacred temple. Therefore, it is sacred in various religious treatments. The same thing also explained Utama (2013), a religion is related to religious, social, and ethical norms. Thus, the practice of religion is a realization related to the problems of daily life unlike, discourse about sacredness. Sacred discourse may be expressed as a conceptual discourse. It produces a form of knowledge, namely "ideas" in the form of knowledge about religious matters. Foucault (2016), stated that the discourse is a conceptual whole in which knowledge. There is formed and produced. The discourse is the whole aspect in which used custom in a certain manner.

Foucault (2016), mentioned that rules, systems, places, and procedures are called discourse. It defines the whole conceptual place where knowledge is formed and produced. The discourse is the whole aspect wherein language is used in a certain manner. The discourse theory provides rejection of the center or starting point of thought. If there must be a center, the center is the language or text. It has the most role in shaping and imaging knowledge for influential subjects and objects in it. There is seen as the real science and practice in social life namely, science and power. It creates the subject of social sciences and their objects unlike, disease, madness, and so on (Ritzer \& Goodman, 2012). Foucault (2016), showed that discourse plays an important role in shaping influential knowledge images. In term of this, Pura Dalem Solo is a religious media has a pattern of intercultural communication for example, the subject and object clearly show the relationship on the power of social relations. Therefore, the cultural discourse in Pura Dalem Solo is no different from the discourse of cultural power. It moves pangempon-penyiwi residents to believe that Pura Dalem Solo is a sacred place that shows the cultural emporium or cultural storefront. It gives rise to strong multiculturalism values.

Regarding the context, the intended discourse is religious tradition practiced aspect for the pengempon-penyiwi residents in Pura Dalem Solo who gave create to intercultural communication patterns. If it is viewed from the

Dasih, I. G. A. R. P., Triguna, I. B. G. Y., \& Winaja, I. W. (2019). Intercultural communication based on ideology, theology and sociology. International Journal of Linguistics, Literature and Culture, 5(5), 29-35. 
perspective of post-structuralism theory. The discourse, in this case, is not only related to the structure of text discourse but also the structure of discourse in the form of ideas. It creates a knowledge-based on experience and action (tradition). Therefore, there is no central point of discourse originating from an oral source related to culture, but from various sources. It defines that the discourse portrays Pura Dalem Solo as an object and pengemponpenyiwi as an object. They have a unity forming knowledge of culture. Therefore, the discourse is seen as real science and practice in social life. There is science and power. The discourse creates the subject of social sciences and the objects within cultural context (Foucault, 2016).

The two-way traffic communication pattern in Pura Dalem Solo places pengempon-penyiwi residents not only as communicants who receive and receiver, but also they have the right to communicate everything to the temple administrators. There is a two-way or lead interaction behind. As explained earlier, the two-way communication is a process of communication occurs between the communicator and the communicant to exchange functions in carrying out their respective functions. Thus, the pattern involves the interaction of pengempon-penyiwi and other pamedek who offer prayers there. In this context, the dialogue occurs not only regarded as ritual, but also cultural dialogue is as social capital. The cultural dialogue took place involved three forms of culture, namely Balinese, Javanese, and Chinese cultures. All religious symbols and attributes can be expressed as a medium for interaction. It gives rise to patterns of mutual communication. The pattern is implemented through bhakti (community service), as devotion to Ida Sesuhunan (God) can eliminate fear, anger, hatred, and envy. It is stated in Bhagawadgita XII.17 as follows.

Yo na hriśhyati na dveshti,
Na sochāti nā kankshati,
Bhaktiman ya same priyah.

Translation:

S/he who has no fun and hates, no grieving and lust for what, freeing her/himself from evil and a sense of doing good, full of worship, s/he is the one I love (Maswinara, 1999).

This communication, in fact, represents a concept of fertility. Wherein the fertility and prosperity would not occur. If there were no communication and interaction between citizens. The integrated concept culturally between two elements is clearly known. Therefore, it will occur fertility. They will never be able to achieve prosperity and fertility if there is no interaction between citizens. Due to the prosperity and fertility are related to how citizens can accumulate capital in the realm. Pura Dalem Solo may be declared as the realm, and in the realm of habitus multiplied by capital will manifest practices on accumulating terms for all capital. In this context, of course, the capital in question is cultural and economic capital.

\subsection{Intercultural Communication Implication}

The existence of intercultural communication in Pura Dalem Solo has implications for the belief and similarity views. There is a cultural replica. It is automatically communicated, both verbally and nonverbally. Thus, refugees are encouraged to take sacred actions. Winaja (2017), explained that sacred acts are carried out when in contact with religion. Even, Hinduism in Bali, the sacredness is in local beliefs as a transformation of local wisdom. Of course, all raise implications related to reinforcement of the mental and spiritual aspects of the citizens. It defines strengthen the belief. Pura Dalem Solo is the locus or orientation of the cosmos for fertility and cultural worship on it, namely as capital.

Strengthening social capital is very important. Due to the social capital is a resource can be seen as an investment to get new resources, the cultural, and economic capital. Therefore, the factual finding on the current study indirectly been used as social capital to invest. The effort is to accumulate economic and cultural capital. Economic capital on making discourse and symbols about fertility is as a medium of communication for the citizens investing material and money. There is cultural capital on making the three cultures as knowledge and discourse in maintaining a multicultural paradigm.

Strengthening has also occurred on the relationship harmony aspect called tri hita karana as a real realization. Implications have also occurred on the seven culture elements. They are normalized into the dialectic form of cultural attitudes, cultural behavior, and culture without realizing. It has become a natural hegemony. The culture as a ruler that has a power relation to unite the pengempon-penyiwi societies into socio-cultural ties. It is based on local 
traditions, namely Hinduism as a base. It creates harmonious relations of intercultural communication in Pura Dalem Solo.

\section{Conclusion}

It can be concluded the process of intercultural communication in Pura Dalem Solo. There are intercultural magic discourse, intercultural symbolic communication, and intercultural ideological communication. The pattern of intercultural communication implemented in Pura Dalem Solo is one-way and two-way. The communication contains religious, social, and ethical values based on Hinduism. The implications of intercultural communication systems for cultural diversity in Pura Dalem Solo are strengthening religious attitudes unlike, strengthening mental, spiritual attitudes, and strengthening fertility ideologies. Likewise, strengthening of local traditions aspects and aspects strengthening of tri hita karana in the social environment, strengthening of cultural values. There are a strengthening seven culture elements and cultural attitudes, and the cultural education system related to strengthening of affective aspects of cultural cognition and cultural behavior.

\section{Conflict of interest statement}

The authors declared that they have no competing interest.

Statement of authorship

The authors have a responsibility for the conception and design of the study. The authors have approved the final article.

\section{Acknowledgments}

The authors would like to thank the editor of IJLLC for their valuable time, support, and advice on completing the current study.

Dasih, I. G. A. R. P., Triguna, I. B. G. Y., \& Winaja, I. W. (2019). Intercultural communication based on ideology, theology and sociology. International Journal of Linguistics, Literature and Culture, 5(5), 29-35. 


\section{References}

DeVito, M. A., Birnholtz, J., \& Hancock, J. T. (2017, February). Platforms, people, and perception: Using affordances to understand self-presentation on social media. In Proceedings of the 2017 ACM conference on computer supported cooperative work and social computing (pp. 740-754). ACM. https://doi.org/10.1145/2998181.2998192

Endraswara, S. (2017). Antropologi wayang: simbolisme, mistisisme, dan realisme hidup. Morfalingua.

Foucault, M., Pelican, Č., Petř́ček, M., Polášek, S., Soukup, P., \& Thein, K. (2016). Thinking outside . Herrmann \& Sons.

Liu, X. (2018). International communication of intangible cultural heritage in central plains: a case study of Chinese Wushu. International Journal of Social Sciences and Humanities, 2(3), 196-204. https://doi.org/10.29332/ijssh.v2n3.238

Maswinara, I. W. (1999). Bhagawadgita. Surabaya: Paramita.

Ritzer, G. (2012). Grobalization. The Wiley-Blackwell Encyclopedia of Globalization. https://doi.org/10.1002/9780470670590.wbeog260

Sabilah, F. (2016). Teaching techniques and instructional media in presenting intercultural awareness in English class of primary school students. International Journal of Linguistics, Literature and Culture, 2(4), $112-121$.

Triguna, I. B. G. Y. (2017). Budaya inspiratif dan pembangunan karakter: bunga rampai pemikiran tentang agama dan kebudayaan. Pascasarjana, Universitas Hindu Indonesia.

Utama, W. B., \& Budi, W. (2013). Agama dalam Praksis Budaya. Denpasar: Pascasarjana Universitas Hindu Indonesia.

Winaja, I. W. (2017). Transformasi Kearifan Lokal, dan Pendidikan Karakter Dalam Pertunjukan Wayang Cenblonk. Denpasar: UNHI Cakra Press. 


\section{Biography of Authors}

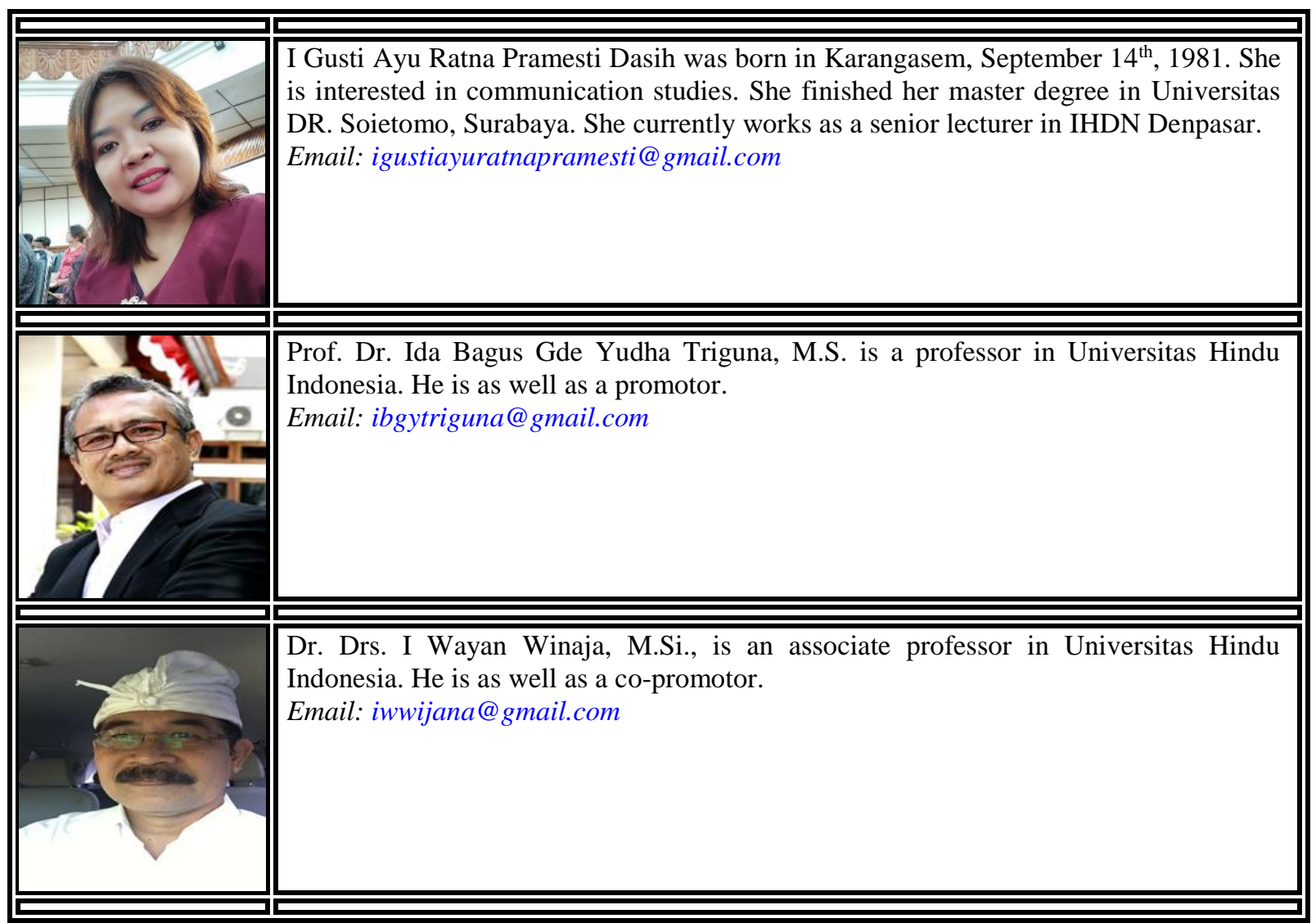

Dasih, I. G. A. R. P., Triguna, I. B. G. Y., \& Winaja, I. W. (2019). Intercultural communication based on ideology, theology and sociology. International Journal of Linguistics, Literature and Culture, 5(5), 29-35. https://doi.org/10.21744/ijllc.v5n5.738 